\title{
Diagnosis, Assessment, and Therapeutic Strategy for Colorectal Mixed Adenoneuroendocrine Carcinoma
}

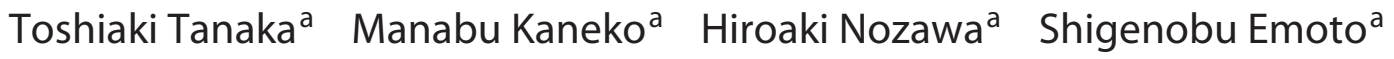 \\ Koji Murono $^{a}$ Kensuke Otani $^{a}$ Kazuhito Sasaki $^{a}$ Takeshi Nishikawa $^{a}$ \\ Tomomichi Kiyomatsu $^{a}$ Keisuke Hata ${ }^{a}$ Teppei Morikawa ${ }^{b}$ Kazushige Kawai ${ }^{a}$ \\ Toshiaki Watanabe ${ }^{a}$ \\ Departments of a Surgical Oncology and b Pathology, University of Tokyo, Tokyo, Japan
}

\section{Keywords}

Mixed adenoneuroendocrine carcinoma $\cdot$ Colon $\cdot$ Rectum

\section{Abstract}

Colorectal mixed adenoneuroendocrine carcinoma (MANEC), which acts like an aggressive tumor, is a rare clinical manifestation on which only a limited amount of literature exists. Surgical resection by regional lymphadenectomy is considered as the only curative treatment for colorectal MANEC, and adjuvant chemotherapy or radiotherapy is recommended because of its high recurrence rate. Colorectal MANEC is frequently diagnosed at an advanced stage, when it is unresectable, and chemotherapy plays a central role in its treatment. Pathological confirmation of the target lesion component is critical for regimen selection. If the lesion comprises an adenocarcinomatous component, a regimen for colorectal adenocarcinoma should be administered. For lesions comprising mainly a neuroendocrine carcinomatous component, cisplatin combined with etoposide or irinotecan has proven to be clinically appropriate. Everolimus, a mechanistic target of rapamycin pathway inhibitor, also improves survival. Sunitinib malate, another molecular target-

\section{KARGER}

(C) 2017 S. Karger AG, Basel

E-Mail karger@karger.com

www.karger.com/nen ing agent, is effective for treating neuroendocrine carcinoma; however, the evidence on its effectiveness for treating gastrointestinal neuroendocrine carcinoma is insufficient.

(c) 2017 S. Karger AG, Basel

\section{Introduction}

Neuroendocrine tumors account for a minority of cases of gastrointestinal tumors [1]; however, the incidence of these tumors is gradually increasing according to the Surveillance, Epidemiology, and End Results database of the USA [2]. The rectum is the most common primary site of gastrointestinal neuroendocrine tumors, followed by the jejunum/ileum, stomach, and colon. The distribution of these tumors differs by race and sex. According to the World Health Organization in 2010, neuroendocrine tumors are classified as G1, G2, or G3 (neuroendocrine carcinoma) based on the mitotic count or Ki-67 index (Table 1). Mixed adenoneuroendocrine carcinoma (MANEC) comprises neoplasms containing both neuroendocrine carcinomatous and adenocarcinomatous components. To meet the definition of MANEC, both com-

Toshiaki Tanaka, MD, PhD

Department of Surgical Oncology

University of Tokyo

7-3-1 Hongo, Bunkyo-Ku, Tokyo 113-0033 (Japan)

E-Mail toshi-t@venus.dti.ne.jp 
Fig. 1. Colonoscopic (a, c) and CT (b, d) images of rectal mixed adenoneuroendocrine carcinoma at initial diagnosis $(\mathbf{a}, \mathbf{b})$ and 4 weeks after neoadjuvant chemoradiotherapy $(\mathbf{c}, \mathbf{d})$.
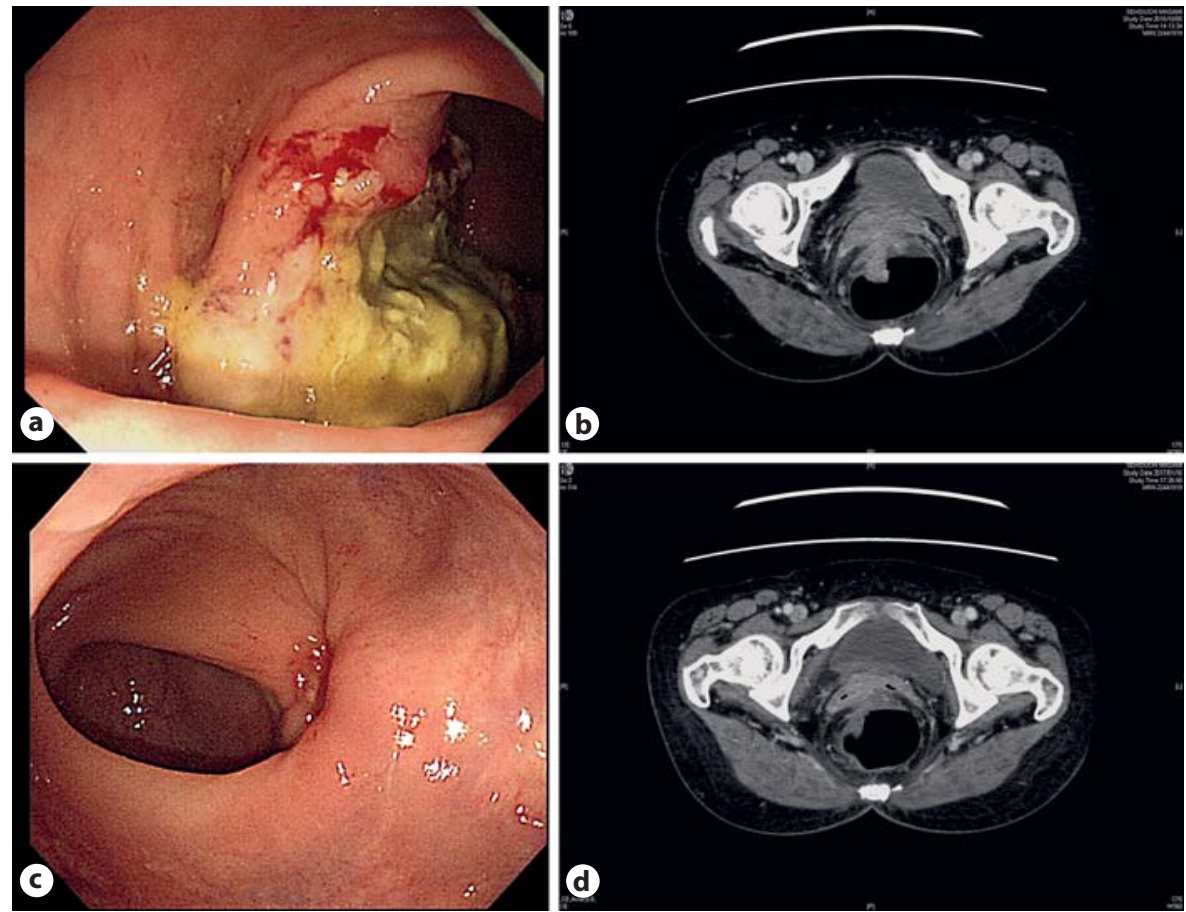

Table 1. World Health Organization 2010 classification of NETs

\begin{tabular}{llll}
\hline Grade & Gastroenteropancreatic NET & Lung and thymus & Differentiation \\
\hline Low (G1) & $<2$ mitoses/10 HPFs and/or & $<2$ mitoses/10 HPFs and no necrosis & Well-differentiated NET \\
& Ki-67 index $<3 \%$ & & \\
\hline Intermediate (G2) & $2-20$ mitoses/10 HPFs and/or & $2-10$ mitoses/10 HPFs and/or foci of necrosis & Well-differentiated NET \\
& Ki-67 index 3-20\% & & Poorly differentiated \\
High (G3) & $>20$ mitoses/10 HPFs and/or & $>10$ mitoses/10 HPFs & neuroendocrine carcinoma \\
\hline
\end{tabular}

NET, neuroendocrine tumor; HPF, high-power field.

ponents must constitute at least $30 \%$ of the tumor and be separately graded as carcinomas [3].

Owing to this dual histology, the clinical behavior of MANEC differs from that of neuroendocrine carcinoma or adenocarcinoma; however, no clinical practice guidelines have yet been developed, and the National Comprehensive Cancer Network (NCCN) guidelines (version 1.02017) do not include the management of MANEC. Furthermore, only a limited number of studies on MANEC have been published. Herein, we review these studies and discuss the clinicopathological features, therapeutic options, and outcomes of colorectal MANEC.

Colorectal Mixed Adenoneuroendocrine Carcinoma

\section{Diagnosis of MANEC}

\section{Colonoscopic Examination}

Colonoscopy is the most reliable modality for the definite diagnosis of colorectal neoplasms. Reportedly, neuroendocrine carcinoma progresses rapidly and is often advanced when diagnosed. Its morphology is similar to that of advanced adenocarcinoma, which differs from that of neuroendocrine tumors (G1 or G2) generally presenting as a submucosal tumor with or without delle.

MANEC also acts as an aggressive tumor and presents at an advanced stage. Most studies indicate that MANEC

Neuroendocrinology 2017;105:426-434 427 

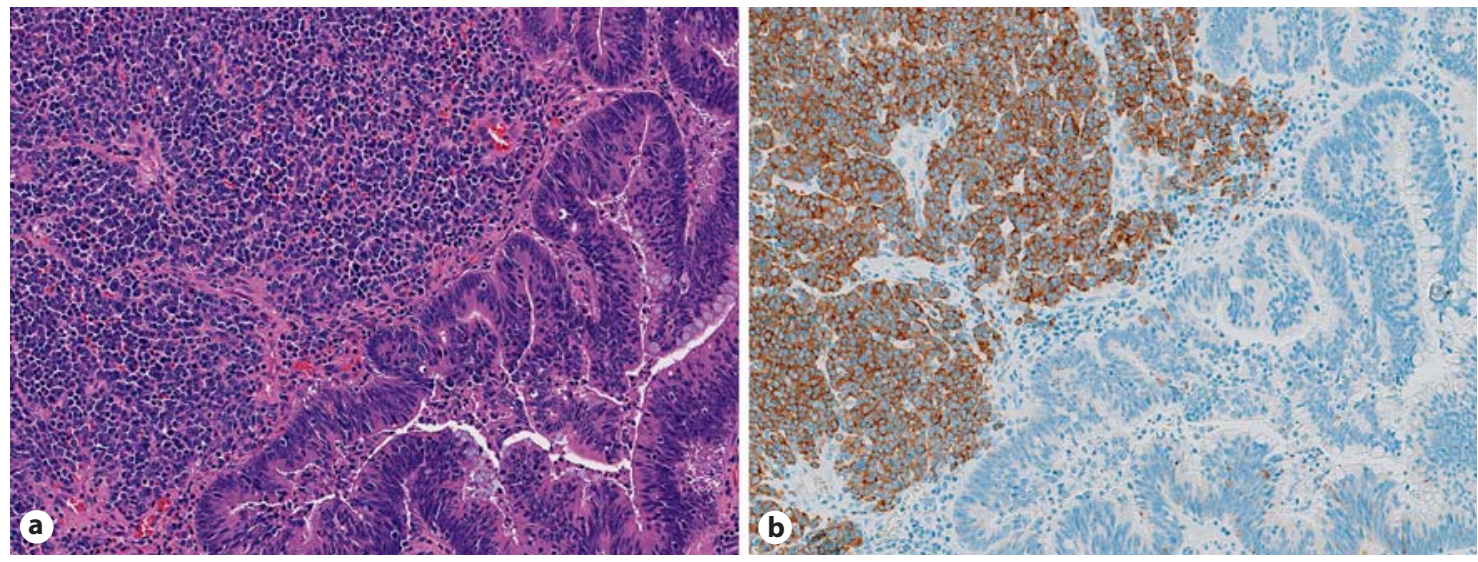

Fig. 2. a Boundary area between the two components of rectal mixed adenoneuroendocrine carcinoma on HE staining. b Neuroendocrine components with strong synaptophysin immunoreactivity.

generally forms a semicircular tumor with deep ulceration (type 2 tumor) [3-6] or presents as a prominent tumor (type 1 tumor) occupying the lumen [7]. Furthermore, large tumors occasionally cause colonic intussusception. The shape of MANEC tumors is similar to that of colorectal adenocarcinoma, and, therefore, the morphologic distinction between MANEC and colorectal adenocarcinoma using endoscopic images is difficult (Fig. 1).

\section{Pathological Diagnosis and Histological Classification}

Specimen biopsies and pathological examination are crucial for a diagnosis. MANEC is defined by the WHO 2010 classification as a tumor composed of both neuroendocrine carcinoma and adenocarcinoma (Fig. 2). Therefore, tumors previously classified as goblet cell carcinoid (GCC), adenocarcinoma ex GCC, and mixed endocrine-exocrine tumor [8] were excluded from the classification of MANEC because they do not contain a neuroendocrine carcinomatous component. However, GCCs are another important entity, and we should determine the details of this differential diagnosis in clinical practice. GCC tumors are divided into three groups according to their components. Typical GCC (group A) consists of well-defined goblet cells arranged in clusters or in a cohesive linear pattern, with minimal cytologic atypia. Adenocarcinoma ex GCC, signet ring cell type (group B), was defined as goblet cells or signet ring cells in irregular large clusters with a single-cell infiltration pattern and significant cytologic atypia. Adenocarcinoma ex GCC, poorly differentiated adenocarcinoma (group C), was defined by focal evidence of goblet cells, not otherwise morphologi- cally distinguishable from a poorly differentiated adenocarcinoma. A favorable 5-year survival rate of $100 \%$ was revealed in GCC group A patients; in contrast, survival rates of 36 and $0 \%$ were shown for group $B$ and group $C$ patients, respectively [9]. Although GCC does not meet the criteria for MANEC, an undifferentiated subtype shows poor outcomes similar to those of MANEC.

The neuroendocrine components of MANEC are classified into small cell or large cell carcinoma. They are morphologically similar to neuroendocrine carcinoma of the lung, and a classification was proposed by La Rosa et al. [10] and Travis et al. [11]. Histologically, small cell carcinoma-type MANEC presents small- or intermediate-sized cells with scant cytoplasm and fusiform nuclei with granular chromatin and inconspicuous nucleoli. In large cell MANEC, the neuroendocrine components present large cells with a polygonal shape, abundant cytoplasm, coarse chromatin, and frequent nucleoli [10, 12]. The incidence and impact on survival of MANEC with regard to this differentiation between components have not been reported. However, a national cohort study concerning gastroenteropancreatic neuroendocrine tumor will be a good reference. Although the survey was not limited to cases of colon and rectum cancer, the incidence rates of large and small cell carcinoma of gastroenteropancreatic neuroendocrine tumor were 61 and 39\%, respectively. Additionally, the results revealed that the type of carcinoma did not affect survival (large vs. small cell neuroendocrine carcinoma: $\mathrm{HR}=1.10, p=0.61$ ). Currently, there is no different therapeutic strategy proposed for neuroendocrine carcinoma with regard to its histological subtype. Overall, the subtype of MANEC is not 
considered to influence patient survival and the treatment modality.

From another pathological viewpoint, MANEC composition is classified as collision, composite, or amphicrine according to the arrangement of the neuroendocrine and glandular cells. In collision tumors, adenocarcinoma and neuroendocrine cells are arranged alongside, suggesting that the tumor originates from two cells. By contrast, these components intermingle in composite tumors, and in amphicrine tumors, neuroendocrine and adenocarcinomatous characteristics appear together within the same tumor cells. Composite and amphicrine tumors are considered to arise from single cells, and multidirectional differentiation results in these histological characteristics $[13,14]$. Owing to the histology of collision tumors, biopsy specimens occasionally contain only one of the two carcinoma components, which results in an incorrect pathological diagnosis. Therefore, sufficient tissue samples from various parts of the tumor should be obtained to avoid misdiagnosis.

\section{Staging}

Staging is crucial in planning the therapeutic strategy for MANEC. In colorectal adenocarcinomas, regional lymph node involvement is routinely investigated with contrast-enhanced computed tomography (CT). Previous reports have indicated that lymph nodes $>1 \mathrm{~cm}$ in diameter, 3 or more clustered lymph nodes regardless of size, and an irregular lymph node surface are predictive factors for lymph node involvement with a sensitivity of 66-96.3\% [15-25]. In contrast, Kim et al. [26] reported that $24.5 \%$ of lymph nodes $<5 \mathrm{~mm}$ in diameter test positive for metastasis from neuroendocrine tumors, the rate of which increases with the increase in lymph node diameter (6.14- and 2.91-mm diameters of positive and negative lymph nodes, respectively). We also reported in a preliminary study that a lymph node $>5 \mathrm{~mm}$ in diameter in the pericolic/perirectal field is predictive of lymph node metastasis from neuroendocrine tumors. Smaller lymph nodes are involved in metastasis from neuroendocrine tumors rather than from adenocarcinoma. We suggest that more stringent criteria for lymph node metastasis be applied to MANEC evaluated using CT images; however, evidence on the efficacy of CT for MANEC staging is still lacking.

${ }^{18} \mathrm{~F}$-fluorodeoxyglucose positron emission tomography is another modality for detecting nodal involvement in neuroendocrine tumors. However, its sensitivity in colorectal adenocarcinoma and neuroendocrine tumors is low (42.9 and 33\%, respectively) [27, 28], and, there-

Colorectal Mixed Adenoneuroendocrine Carcinoma fore, it is inapplicable to MANEC in clinical practice. Rectal magnetic resonance imaging and ultrasonography are the preferred modalities for determining regional lymph node metastasis.

In neuroendocrine carcinoma, a tumor size $>2 \mathrm{~cm}$ in diameter and invasion into the muscularis propria (T3 and T4) reportedly increased the risk of lymph node metastasis to 80\% [29]; however, the clinicopathological risk factors for lymph node metastasis in MANEC have not yet been investigated.

\section{Therapeutic Strategy}

\section{Surgical Resection}

The North American Neuroendocrine Tumor Society and NCCN guidelines recommend that neuroendocrine tumors $>2 \mathrm{~cm}$ in diameter that have invaded the muscularis propria as well as tumors with lymphovascular invasion or locoregional lymph node involvement be managed with surgical resection, including low anterior or abdominoperineal resection [30, 31]. In contrast, in colorectal adenocarcinoma, tumors invading the sm3 layer should be managed with resection and lymphadenectomy. Given these criteria for neuroendocrine carcinoma and adenocarcinoma, similar criteria should be applied to colorectal MANEC despite the lack of published studies $[29,32]$.

The NCCN guidelines recommend the resection of distant metastases from neuroendocrine tumors if complete resection is expected. Several studies on metastatic neuroendocrine tumors have stated that hepatectomy improves the survival rate, with low operative mortality [33-36]. A high rate of symptom control (104 of 108 patients; $96.2 \%$ ) was also observed, even though the recurrence rate was reported to be 59\% [37]. Although studies on neuroendocrine carcinoma or MANEC have not yet been published, surgical resection should be considered for metastases, because it is the only curative treatment option.

Compared with the survival rate of adenocarcinoma patients, that of patients with MANEC is substantially worse, presumably because of the high-grade components of neuroendocrine tumors. Wang et al. [38] reported a poor 2-year survival of $50 \%$ of patients after surgical resection. In contrast, survival is favorable if the tumor is removed at an early stage. Watanabe et al. [39] reported a 5 -year survival rate of $100 \%$ for patients with stage I tumors compared with 72.7 and $65.5 \%$ for patients with stage II and stage III tumors, respectively.

Neuroendocrinology 2017;105:426-434 DOI: $10.1159 / 000478743$ 


\section{Conversion Therapy for Distant Metastases}

In patients with MANEC, distant metastases should be resected if possible. If initial resection is impossible because of the tumor size or distribution, conversion therapy after chemotherapy should be considered.

According to the results of the CELIM study, 34\% of their patients with initially unresectable liver metastasis from colorectal adenocarcinoma underwent $\mathrm{R} 0$ resection after treatment with FOLFOX/FOLFIRI plus cetuximab [35]. In this study, the improved mean overall survival and progression-free survival after resection was 53.9 and 15.4 months, respectively, compared with 21.9 and 6.9 months, respectively, for patients who did not undergo resection [40]. The effectiveness of conversion therapy with a 5-fluorouracil (5-FU)-based regimen is apparent in metastatic colorectal adenocarcinoma.

In contrast, the regimen for neuroendocrine carcinoma differs from that for adenocarcinoma and is based primarily on cis-diamminedichloroplatinum administration. The mixed histology of MANEC complicates its management. Watanabe et al. [39] reported that the immunohistochemical staining of metastasized tissue in 9 patients with recurrent MANEC demonstrated a neuroendocrine carcinomatous component in 5 patients and an adenocarcinomatous component in 4 patients. These results indicate that in most patients with MANEC, only one of the two components metastasizes and that the histology of distant metastases should be confirmed by biopsy before planning a chemotherapeutic strategy for managing initially unresectable metastases.

\section{Neoadjuvant Chemoradiotherapy for Rectal MANEC}

The results of the Swedish Rectal Trial demonstrate that compared with surgery alone, the addition of preoperative radiotherapy improves survival in advanced rectal adenocarcinoma [41]. Furthermore, the FFCD 9203 trial demonstrated that preoperative radiotherapy with 5-FU and leucovorin (LV) is superior to preoperative radiotherapy, with improved late local control [42]. In addition, a high rate of sphincter preservation is a benefit from preoperative chemoradiotherapy [43]. Therefore, preoperative chemoradiotherapy was standardized for tumors classified as T3-4/N any lower rectal adenocarcinoma in Europe and the USA [44, 45]. On the contrary, few physicians have performed preoperative chemoradiotherapy for neuroendocrine tumors, and its efficacy remains uncertain $[46,47]$. Because the nature of neuroendocrine carcinoma is similar to that of small cell carcinoma, a substantial response to chemoradiotherapy is expected [48]. Therefore, neoadjuvant treatment for
MANEC is justified, and future studies should investigate this modality.

We reported the case of a 54-year-old woman who underwent preoperative chemoradiotherapy for lower rectal MANEC. Although this treatment is not standardized for MANEC in Japan, we performed chemoradiotherapy (50.4 Gy/28 Fr; tegafur-uracil, $500 \mathrm{mg} /$ day) because only the adenocarcinomatous component (tub2+por) was observed in the colonoscopically biopsied specimen before treatment. After chemoradiotherapy, the tumor shrunk, and the ulcer bed was substantially reduced (Fig. 1). Six weeks later, the patient underwent lower abdominal rectal resection and removal of the right lateral lymph nodes for evaluation of suspected metastasis. The specimen demonstrated MANEC (small cell carcinoma $>$ tub1+tub2) without regional lymph node metastasis. Although the rates of response to preoperative chemoradiotherapy appear promising, the components of the target cells should be examined further when planning chemoradiotherapy (cisplatin or 5-FU based), and the impact on survival should be discussed.

\section{Adjuvant Treatment}

Because of the high recurrence rate and poor outcome, adjuvant treatment is recommended for neuroendocrine carcinoma after $\mathrm{R} 0$ resection. A regimen based on cisplatin with etoposide or topotecan, a FOLFOX regimen, a vincristine-based regimen with Adriamycin, or a regimen based on carboplatin and etoposide are reported candidates for treating neuroendocrine carcinoma [30, 31,47 , and adjuvant radiotherapy is also recommended for improved survival. The introduction of platinum-oriented adjuvant treatment or radiation for neuroendocrine carcinoma was based on the use of these regimens for small cell lung carcinoma, which shows a histological similarity to small cell neuroendocrine carcinoma. In addition, an efficacy of adjuvant chemoradiotherapy for large cell neuroendocrine carcinoma was also reported [49]; therefore, these regimens should also be candidates regardless of the MANEC subtype $[39,50]$, though substantial evidence on their efficacy is lacking because most of them have been reported in case series studies.

\section{Management of Recurrent or Unresectable Tumors}

Because of its aggressive nature, colorectal MANEC is often diagnosed at an advanced stage and may not be amenable for surgical resection. In such cases, chemotherapy plays a primary role in treatment. Because MANEC comprises two components that have different responses to chemotherapy, clinicians must determine which component to target.
Tanaka et al. 
Table 2. Proposed regimens for unresectable colorectal MANEC when the target lesion is predominantly neuroendocrine carcinomatous

\begin{tabular}{|c|c|c|c|c|c|}
\hline Study [Ref.] & $\begin{array}{l}\text { Patients, } \\
n\end{array}$ & Involvement & Regimen & $\begin{array}{l}\text { Response } \\
\text { rate, \% }\end{array}$ & $\begin{array}{l}\text { Survival, } \\
\text { months }\end{array}$ \\
\hline Mitry [58] & 41 & Gastroenteropancreatic & $\begin{array}{l}\text { Etoposide }+ \\
\text { cisplatin }\end{array}$ & $\begin{array}{l}\text { CR: } 9.8 \\
\text { PR: } 31.7 \\
\text { SD: } 34.1 \\
\text { PD: } 24.4\end{array}$ & $\begin{array}{l}\text { OS: } 15 \\
\text { PFS: } 8.9\end{array}$ \\
\hline Hainsworth [61] & 78 & $\begin{array}{l}\text { Various sites (gastrointestinal, } \\
\text { lung, skin, prostate, and others) }\end{array}$ & $\begin{array}{l}\text { Paclitaxel }+ \\
\text { carboplatin }+ \\
\text { etoposide }\end{array}$ & $\begin{array}{l}\text { CR: } 15 \\
\text { PR: } 37 \\
\text { SD: } 30 \\
\text { PD: } 9\end{array}$ & $\begin{array}{l}\text { OS: } 14.5 \\
\text { PFS: } 7.5\end{array}$ \\
\hline Raymond [67] & 86 & Pancreas & Sunitinib & $\begin{array}{l}\text { CR: } 2.3 \\
\text { PR: } 7\end{array}$ & PFS: 11.4 \\
\hline Yamaguchi [59] & 142 & Gastrointestinal & $\begin{array}{l}\text { Irinotecan }+ \\
\text { cisplatin }\end{array}$ & CR + PR: 51 & $\begin{array}{l}\text { OS: } 13.4 \\
\text { PFS: } 5.4\end{array}$ \\
\hline Yao [65] & 205 & Gastrointestinal, lung & Everolimus & $\begin{array}{l}\text { PR: } 4 \\
\text { SD: } 81\end{array}$ & PFS: 11.0 \\
\hline
\end{tabular}

Evidence is provided for neuroendocrine carcinoma. MANEC, mixed adenoneuroendocrine carcinoma; CR, complete response; $\mathrm{PR}$, partial response; $\mathrm{SD}$, stable disease; $\mathrm{PD}$, progressive disease; OS, overall survival; $\mathrm{PFS}$, progression-free survival.

A previous report noted that either of the two components can be present in metastatic lesions [39]; therefore, a biopsy of the recurrent lesion or a distant metastasis can confirm which MANEC component is predominant, which aids in regimen selection [39]. Somatostatin receptor scintigraphy is an effective modality for detecting the neuroendocrine carcinoma component in target lesions. Binderup et al. [51] reported that $69 \%$ of high-grade neuroendocrine tumors exhibit positive somatostatin receptor (SSTR) scintigraphy findings.

If the target lesion has an adenocarcinoma component, established regimens for colorectal adenocarcinoma are options for treatment. Oxaliplatin should be added to 5-FU/L-LV as a first-line regimen because it improves the response rate compared with that to $5-\mathrm{FU} / \mathrm{L}-\mathrm{LV}$ alone (50.7 and $22.3 \%$, respectively) and increases progression-free survival (9.0 and 6.2 months, respectively) [52]. Combination therapy with bevacizumab should also be considered, given that Tyagi and Grothey [53] reported a median progression-free survival of 9.4 months and an overall survival of 21.3 months using this agent. For wild-type K-ras tumors, an anti-epidermal growth factor receptor agent contributed to improved survival in the OPUS trial [54]. If the performance status is unaffected

Colorectal Mixed Adenoneuroendocrine

Carcinoma after failure of these regimens, TAS-102 or regorafenib are alternatives for palliative chemotherapy [55-57].

If the target lesion predominantly comprises a neuroendocrine carcinoma component, cisplatin plus etoposide, which offers a response rate of $41.5 \%$ and a median progression-free survival of 8.9 months, should be considered as a first-line regimen [58]. Yamaguchi et al. [59, $60]$ reported that the combination of cisplatin and irinotecan offers a response rate of $51 \%$ and a progression-free survival of 5.2 months for neuroendocrine carcinomas of various organs, as well as an overall survival of 7.6 months for colorectal neuroendocrine carcinomas in particular. Hainsworth et al. [61] used a more aggressive regimen including paclitaxel, carboplatin, and etoposide and reported a response rate of 53\% (complete response rate: $15 \%)$ and a median progression-free survival of 7.5 months. In addition to these cytotoxic regimens, everolimus, an oral inhibitor of mechanistic target of rapamycin (mTOR) is a candidate for treating unresectable neuroendocrine tumors. Although mutations of mTOR pathway genes are infrequently detected in gastrointestinal neuroendocrine tumors, mTOR overexpression and its downstream activity are implicated in adverse clinical outcomes $[62,63]$. 
In RADIANT-4, a phase III trial, everolimus was demonstrated to be superior to placebo for improving the median progression-free survival with gastrointestinal or lung neuroendocrine tumors (11.0 and 3.9 months, respectively) $[64,65]$. Sunitinib malate, an oral multi-target tyrosine kinase inhibitor, inhibits the signal transduction of the vascular endothelial growth factor receptor and platelet-derived growth factor receptor pathways, stemcell factor receptor, and glial cell-derived neurotrophic factor [66]. A phase III trial of patients with low-to-intermediate progressive pancreatic neuroendocrine tumors demonstrated improved progression-free survival with sunitinib malate compared with best supportive care (11.1 and 5.5 months, respectively) [67], although evidence on the effectiveness of this agent for treating gastrointestinal neuroendocrine carcinoma is lacking (Table 2).

The introduction of somatostatin analogs (SSA) for neuroendocrine tumor is a therapeutic option for G1 and G2 neuroendocrine tumor [68]. Octreotide and lanreotide, well-known SSA, have high affinity for SSTR-2 and -5 . However, it has been reported that SSTR-5 was expressed in $0 \%$ of neuroendocrine carcinomas, while it was positive in 81.8 and $60 \%$ of G1 and G2 neuroendocrine tumors, respectively $[69,70]$. Conversely, only a single study showed a $100 \%$ SSTR-2 expression rate in gas- troenteropancreatic neuroendocrine carcinoma [69], but this study included only one rectal neuroendocrine carcinoma case, which is inadequate evidence to support the introduction of SSA for neuroendocrine carcinoma components.

A previous study has revealed that the exocrine and endocrine components of MANEC have a common genetic alteration, indicating that both components have a common oncogenic pathway from the same cellular origin. Vortmeyer et al. [71] showed that both components had identical loss of heterozygosity in APC, DCC, and TP53 in a series of 7 patients. A recent study [72] showed that KRAS mutations on the identical locus in both tumor components were present in 57\% (4 out of 7) of their MANEC patients. KRAS is known as a molecular predictor of the efficacy of anti-EGFR drugs in colorectal adenocarcinoma. Although sufficient evidence is lacking, these common genetic alterations would be a possible target for molecular therapy.

If patients present with paraneoplastic symptoms, such as bowel obstruction, surgery is an alternative, particularly when the tumor is unresponsive to chemotherapy. Debulking is appropriate only when $>90 \%$ of the tumor is reduced $[30,31]$. If sufficient tumor reduction is not expected, options such as bypass or stoma creation should be considered.

\section{References}

1 Stelow EB, Moskaluk CA, Mills SE: The mismatch repair protein status of colorectal small cell neuroendocrine carcinomas. Am J Surg Pathol 2006;30:1401-1404.

2 Yao JC, Hassan M, Phan A, Dagohoy C, Leary C, Mares JE, Abdalla EK, Fleming JB, Vauthey JN, Rashid A, Evans DB: One hundred years after "carcinoid": epidemiology of and prognostic factors for neuroendocrine tumors in 35,825 cases in the United States. J Clin Oncol 2008;26:3063-3072.

3 Liu XJ, Feng JS, Xiang WY, Kong B, Wang LM, Zeng JC, Liang YF: Clinicopathological features of an ascending colon mixed adenoneuroendocrine carcinoma with clinical serosal invasion. Int J Clin Exp Pathol 2014;7: 6395-6398.

4 Ito H, Kudo A, Matsumura S, Ban D, Irie T, Ochiai T, Nakamura N, Tanaka S, Tanabe M: Mixed adenoneuroendocrine carcinoma of the colon progressed rapidly after hepatic rupture: report of a case. Int Surg 2014;99: 40-44.
5 Shin SH, Kim SH, Jung SH, Jang JW, Kang MS, Kim SI, Kim JH, Lee JH: High-grade mixed adenoneuroendocrine carcinoma in the cecum: a case report. Ann Coloproctol 2017;33:39-42.

6 Vanacker L, Smeets D, Hoorens A, Teugels E, Algaba R, Dehou MF, De Becker A, Lambrechts D, De Greve J: Mixed adenoneuroendocrine carcinoma of the colon: molecular pathogenesis and treatment. Anticancer Res 2014;34:5517-5521.

7 Morais M, Pinho AC, Marques A, Lopes J, Duarte A, da Silva PC, Lopes JM, Maia JC: Mixed adenoneuroendocrine carcinoma causing colonic intussusception. Case Rep Surg 2016;2016:7684364.

8 Brathwaite S, Yearsley MM, Bekaii-Saab T, Wei L, Schmidt CR, Dillhoff ME, Frankel WL, Hays JL, Wu C, Abdel-Misih S: Appendiceal mixed adeno-neuroendocrine carcinoma: a population-based study of the Surveillance, Epidemiology, and End Results registry. Front Oncol 2016;6:148.

9 Piao J, Veerapong J: Adenocarcinoma ex goblet cell carcinoid (GCC) of the appendix: report of five cases and pitfalls in diagnosis of GCC. Arch Surg Oncol 2016;2:108.
10 La Rosa S, Marando A, Sessa F, Capella C: Mixed adenoneuroendocrine carcinomas (MANECs) of the gastrointestinal tract: an update. Cancers (Basel) 2012;4:11-30.

11 Travis WD, Linnoila RI, Tsokos MG, Hitchcock CL, Cutler GB Jr, Nieman L, Chrousos G, Pass H, Doppman J: Neuroendocrine tumors of the lung with proposed criteria for large-cell neuroendocrine carcinoma. An ultrastructural, immunohistochemical, and flow cytometric study of 35 cases. Am J Surg Pathol 1991;15:529-553.

12 Pascarella MR, McCloskey D, Jenab-Wolcott J, Vala M, Rovito M, McHugh J: Large cell neuroendocrine carcinoma of the colon: a rare and aggressive tumor. J Gastrointest Oncol 2011;2:250-253.

13 Minaya-Bravo AM, Garcia Mahillo JC, Mendoza Moreno F, Noguelares Fraguas F, Granell J: Large cell neuroendocrine - adenocarcinona [sic!] mixed tumour of colon: collision tumour with peculiar behaviour. What do we know about these tumours? Ann Med Surg (Lond) 2015;4:399-403. 
14 Scardoni M, Vittoria E, Volante M, Rusev B, Bersani S, Mafficini A, Gottardi M, Giandomenico V, Malleo G, Butturini G, Cingarlini S, Fassan M, Scarpa A: Mixed adenoneuroendocrine carcinomas of the gastrointestinal tract: targeted next-generation sequencing suggests a monoclonal origin of the two components. Neuroendocrinology 2014;100:310316.

15 Gazelle GS, Gaa J, Saini S, Shellito P: Staging of colon carcinoma using water enema CT. J Comput Assist Tomogr 1995;19:87-91.

16 Gomille T, Aleksic M, Ulrich B, Christ F: Significance of $\mathrm{CT}$ in the detection of regional lymph node metastases in colorectal carcinoma (in German). Radiologe 1998;38:10771082.

17 Smith NJ, Bees N, Barbachano Y, Norman AR, Swift RI, Brown G: Preoperative computed tomography staging of nonmetastatic colon cancer predicts outcome: implications for clinical trials. Br J Cancer 2007;96:1030-1036.

18 Hundt W, Braunschweig R, Reiser M: Evaluation of spiral CT in staging of colon and rectum carcinoma. Eur Radiol 1999;9:78-84.

19 Dighe S, Purkayastha S, Swift I, Tekkis PP, Darzi A, A'Hern R, Brown G: Diagnostic precision of CT in local staging of colon cancers: a meta-analysis. Clin Radiol 2010;65:708719.

20 Dighe S, Swift I, Brown G: CT staging of colon cancer. Clin Radiol 2008;63:1372-1379.

21 Zerhouni EA, Rutter C, Hamilton SR, Balfe DM, Megibow AJ, Francis IR, Moss AA, Heiken JP, Tempany CM, Aisen AM, Weinreb JC, Gatsonis C, McNeil BJ: CT and MR imaging in the staging of colorectal carcinoma: report of the radiology diagnostic oncology group II. Radiology 1996;200:443-451.

22 Ashraf K, Ashraf O, Haider Z, Rafique Z: Colorectal carcinoma, preoperative evaluation by spiral computed tomography. J Pak Med Assoc 2006;56:149-153.

23 Freeny PC, Marks WM, Ryan JA, Bolen JW: Colorectal carcinoma evaluation with CT: preoperative staging and detection of postoperative recurrence. Radiology 1986;158:347353.

24 Balthazar EJ, Megibow AJ, Hulnick D, Naidich DP: Carcinoma of the colon: detection and preoperative staging by CT. AJR Am J Roentgenol 1988;150:301-306.

25 Burton S, Brown G, Bees N, Norman A, Biedrzycki O, Arnaout A, Abulafi AM, Swift RI: Accuracy of CT prediction of poor prognostic features in colonic cancer. Br J Radiol 2008;81:10-19.

26 Kim BC, Kim YE, Chang HJ, Lee SH, Youk EG, Lee DS, Lee JB, Lee EJ, Kim MJ, Sohn DK, Oh JH: Lymph node size is not a reliable criterion for predicting nodal metastasis in rectal neuroendocrine tumours. Colorectal Dis 2016;18:O243-O251.
27 Pattenden HA, Leung M, Beddow E, Dusmet M, Nicholson AG, Shackcloth M, Mohamed S, Darr A, Naidu B, Iyer S, Marchbank A, Greenwood A, West D, Granato F, Kirk A, Ariyaratnam P, Loubani M, Lim E; UK Thoracic Surgery Collaborative: Test performance of PET-CT for mediastinal lymph node staging of pulmonary carcinoid tumours. Thorax 2015;70:379-381.

28 Lu YY, Chen JH, Ding HJ, Chien CR, Lin WY, Kao CH: A systematic review and meta-analysis of pretherapeutic lymph node staging of colorectal cancer by ${ }^{18} \mathrm{~F}$-FDG PET or PET/ CT. Nucl Med Commun 2012;33:1127-1133.

29 Knigge U, Hansen CP: Surgery for GEPNETs. Best Pract Res Clin Gastroenterol 2012; 26:819-831.

30 Anthony LB, Strosberg JR, Klimstra DS, Maples WJ, O'Dorisio TM, Warner RR, Wiseman GA, Benson AB 3rd, Pommier RF: The NANETS consensus guidelines for the diagnosis and management of gastrointestinal neuroendocrine tumors (NETs): well-differentiated NETs of the distal colon and rectum. Pancreas 2010;39:767-774.

31 Kulke MH, Shah MH, Benson AB 3rd, Bergsland E, Berlin JD, Blaszkowsky LS, Emerson L, Engstrom PF, Fanta P, Giordano T, Goldner WS, Halfdanarson TR, Heslin MJ, Kandeel F, Kunz PL, Kuvshinoff BW 2nd, Lieu C, Moley JF, Munene G, Pillarisetty VG, Saltz L, Sosa JA, Strosberg JR, Vauthey JN, Wolfgang C, Yao JC, Burns J, Freedman-Cass D; National Comprehensive Cancer Network: Neuroendocrine tumors, version 1.2015. J Natl Compr Canc Netw 2015;13:78-108.

32 Fendrich V, Bartsch DK: Surgical treatment of gastrointestinal neuroendocrine tumors. Langenbecks Arch Surg 2011;396:299-311.

33 Touzios JG, Kiely JM, Pitt SC, Rilling WS, Quebbeman EJ, Wilson SD, Pitt HA: Neuroendocrine hepatic metastases: does aggressive management improve survival? Ann Surg 2005;241:776-783; discussion 783-785.

34 Dousset B, Saint-Marc O, Pitre J, Soubrane O, Houssin D, Chapuis Y: Metastatic endocrine tumors: medical treatment, surgical resection, or liver transplantation. World J Surg 1996; 20:908-914; discussion 914-915.

35 Que FG, Nagorney DM, Batts KP, Linz LJ, Kvols LK: Hepatic resection for metastatic neuroendocrine carcinomas. Am J Surg 1995; 169:36-42; discussion 42-43.

36 Chen H, Hardacre JM, Uzar A, Cameron JL, Choti MA: Isolated liver metastases from neuroendocrine tumors: does resection prolong survival? J Am Coll Surg 1998;187:88-92; discussion 92-93.

37 Sarmiento JM, Heywood G, Rubin J, Ilstrup DM, Nagorney DM, Que FG: Surgical treatment of neuroendocrine metastases to the liver: a plea for resection to increase survival. J Am Coll Surg 2003;197:29-37.
38 Wang Z, Li W, Chen T, Yang J, Luo L, Zhang L, Sun B, Liang R: Retrospective analysis of the clinicopathological characteristics of gastrointestinal neuroendocrine neoplasms. Exp Ther Med 2015;10:1084-1088.

39 Watanabe J, Suwa Y, Ota M, Ishibe A, Masui H, Nagahori K, Tsuura Y, Endo I: Clinicopathological and prognostic evaluations of mixed adenoneuroendocrine carcinoma of the colon and rectum: a case-matched study. Dis Colon Rectum 2016;59:1160-1167.

40 Folprecht G, Gruenberger T, Bechstein W, Raab HR, Weitz J, Lordick F, Hartmann JT, Stoehlmacher-Williams J, Lang H, Trarbach T, Liersch T, Ockert D, Jaeger D, Steger U, Suedhoff T, Rentsch A, Köhne CH: Survival of patients with initially unresectable colorectal liver metastases treated with FOLFOX/ cetuximab or FOLFIRI/cetuximab in a multidisciplinary concept (CELIM study). Ann Oncol 2014;25:1018-1025.

41 Swedish Rectal Cancer Trial, Cedermark B, Dahlberg M, Glimelius B, Påhlman L, Rutqvist LE, Wilking N: Improved survival with preoperative radiotherapy in resectable rectal cancer. N Engl J Med 1997;336:980-987.

42 Gerard JP, Conroy T, Bonnetain F, Bouché O, Chapet O, Closon-Dejardin MT, Untereiner M, Leduc B, Francois E, Maurel J, Seitz JF, Buecher B, Mackiewicz R, Ducreux M, Bedenne L: Preoperative radiotherapy with or without concurrent fluorouracil and leucovorin in T3-4 rectal cancers: results of FFCD 9203. J Clin Oncol 2006;24:4620-4625.

43 Sauer R, Becker H, Hohenberger W, Rödel C, Wittekind C, Fietkau R, Martus P, Tschmelitsch J, Hager E, Hess CF, Karstens JH, Liersch T, Schmidberger H, Raab R; German Rectal Cancer Study Group: Preoperative versus postoperative chemoradiotherapy for rectal cancer. N Engl J Med 2004;351: 1731-1740.

44 Glimelius B, Tiret E, Cervantes A, Arnold D; ESMO Guidelines Working Group: Rectal cancer: ESMO clinical practice guidelines for diagnosis, treatment and follow-up. Ann Oncol 2013;24(suppl 6):vi81-vi88.

45 Benson AB 3rd, Venook AP, Bekaii-Saab T, Chan E, Chen YJ, Cooper HS, Engstrom PF, Enzinger PC, Fenton MJ, Fuchs CS, Grem JL, Grothey A, Hochster HS, Hunt S, Kamel A, Kirilcuk N, Leong LA, Lin E, Messersmith WA, Mulcahy MF, Murphy JD, Nurkin S, Rohren E, Ryan DP, Saltz L, Sharma S, Shibata D, Skibber JM, Sofocleous CT, Stoffel EM, Stotsky-Himelfarb E, Willett CG, Gregory KM, Freedman-Cass D: Rectal cancer, version 2.2015. J Natl Compr Canc Netw 2015; 13:719-728; quiz 728.

46 Yin ZM, Yu AJ, Wu MJ, Fang J, Liu LF, Zhu JQ, Yu H: Effects and toxicity of neoadjuvant chemotherapy preoperative followed by adjuvant chemoradiation in small cell neuroendocrine cervical carcinoma. Eur J Gynaecol Oncol 2015;36:326-329. 
47 Aytac E, Ozdemir Y, Ozuner G: Long term outcomes of neuroendocrine carcinomas (high-grade neuroendocrine tumors) of the colon, rectum, and anal canal. J Visc Surg 2014;151:3-7.

48 Takada M, Fukuoka M, Kawahara M, Sugiura T, Yokoyama A, Yokota S, Nishiwaki Y, Watanabe K, Noda K, Tamura T, Fukuda H, Saijo N: Phase III study of concurrent versus sequential thoracic radiotherapy in combination with cisplatin and etoposide for limitedstage small-cell lung cancer: results of the Japan Clinical Oncology Group Study 9104. J Clin Oncol 2002;20:3054-3060.

49 Nojima H, Seike K, Kosugi C, Shida T, Koda K, Oda K, Kamata S, Ishikura H, Miyazaki M: Advanced moderately differentiated neuroendocrine carcinoma of the rectum with favorable prognosis by postoperative chemoradiation. World J Surg Oncol 2010;8:29.

50 Komatsubara T, Koinuma K, Miyakura Y, Horie $\mathrm{H}$, Morimoto $\mathrm{M}$, Ito $\mathrm{H}$, Lefor $\mathrm{AK}$, Sata N, Fukushima N: Endocrine cell carcinomas of the colon and rectum: a clinicopathological evaluation. Clin J Gastroenterol 2016;9:1-6.

51 Binderup T, Knigge U, Loft A, Mortensen J, Pfeifer A, Federspiel B, Hansen CP, Højgaard L, Kjaer A: Functional imaging of neuroendocrine tumors: a head-to-head comparison of somatostatin receptor scintigraphy, ${ }^{123} \mathrm{I}-$ MIBG scintigraphy, and ${ }^{18} \mathrm{~F}$-FDG PET. J Nucl Med 2010;51:704-712.

52 de Gramont A, Figer A, Seymour M, Homerin $\mathrm{M}$, Hmissi A, Cassidy J, Boni C, CortesFunes H, Cervantes A, Freyer G, Papamichael D, Le Bail N, Louvet C, Hendler D, de Braud F, Wilson C, Morvan F, Bonetti A: Leucovorin and fluorouracil with or without oxaliplatin as first-line treatment in advanced colorectal cancer. J Clin Oncol 2000;18:2938-2947.

53 Tyagi P, Grothey A: Commentary on a phase III trial of bevacizumab plus XELOX or FOLFOX4 for first-line treatment of metastatic colorectal cancer: the NO16966 trial. Clin Colorectal Cancer 2006;6:261-264.

54 Bokemeyer C, Bondarenko I, Makhson A, Hartmann JT, Aparicio J, de Braud F, Donea S, Ludwig H, Schuch G, Stroh C, Loos AH, Zubel A, Koralewski P: Fluorouracil, leucovorin, and oxaliplatin with and without cetuximab in the first-line treatment of metastatic colorectal cancer. J Clin Oncol 2009;27:663671.

55 Grothey A, Van Cutsem E, Sobrero A, Siena S, Falcone A, Ychou M, Humblet Y, Bouché $\mathrm{O}$, Mineur L, Barone C, Adenis A, Tabernero J, Yoshino T, Lenz HJ, Goldberg RM, Sargent DJ, Cihon F, Cupit L, Wagner A, Laurent D; CORRECT Study Group: Regorafenib monotherapy for previously treated metastatic colorectal cancer (CORRECT): an international, multicentre, randomised, placebocontrolled, phase 3 trial. Lancet 2013;381: 303-312.
56 Mayer RJ, Van Cutsem E, Falcone A, Yoshino $\mathrm{T}$, Garcia-Carbonero R, Mizunuma N, Yamazaki K, Shimada Y, Tabernero J, Komatsu Y, Sobrero A, Boucher E, Peeters M, Tran B, Lenz HJ, Zaniboni A, Hochster H, Cleary JM, Prenen H, Benedetti F, Mizuguchi H, Makris L, Ito M, Ohtsu A; RECOURSE Study Group: Randomized trial of TAS-102 for refractory metastatic colorectal cancer. N Engl J Med 2015;372:1909-1919.

57 Yoshino T, Komatsu Y, Yamada Y, Yamazaki K, Tsuji A, Ura T, Grothey A, Van Cutsem E, Wagner A, Cihon F, Hamada Y, Ohtsu A: Randomized phase III trial of regorafenib in metastatic colorectal cancer: analysis of the CORRECT Japanese and non-Japanese subpopulations. Invest New Drugs 2015;33:740750.

58 Mitry E, Baudin E, Ducreux M, Sabourin JC, Rufié P, Aparicio T, Aparicio T, Lasser P, Elias D, Duvillard P, Schlumberger M, Rougier P: Treatment of poorly differentiated neuroendocrine tumours with etoposide and cisplatin. Br J Cancer 1999;81:1351-1355.

59 Yamaguchi T, Machida N, Morizane C, Kasuga A, Takahashi H, Sudo K, Nishina T, Tobimatsu K, Ishido K, Furuse J, Boku N, Okusaka T: Multicenter retrospective analysis of systemic chemotherapy for advanced neuroendocrine carcinoma of the digestive system. Cancer Sci 2014;105:1176-1181.

60 Yamaguchi T, Machida N, Kasuga A, Takahashi $\mathrm{H}$, Sudo K, Nishina T, Tobimatsu K, Ishido K, Furuse J, Boku N: Multicenter retrospective analysis of systemic chemotherapy in poorly differentiated neuroendocrine carcinoma of digestive system. J Clin Oncol 2012; 30(suppl):274.

61 Hainsworth JD, Spigel DR, Litchy S, Greco FA: Phase II trial of paclitaxel, carboplatin, and etoposide in advanced poorly differentiated neuroendocrine carcinoma: a Minnie Pearl Cancer Research Network Study. J Clin Oncol 2006;24:3548-3554.

62 Qian ZR, Ter-Minassian M, Chan JA, Imamura Y, Hooshmand SM, Kuchiba A, Morikawa T, Brais LK, Daskalova A, Heafield R, Lin X, Christiani DC, Fuchs CS, Ogino S, Kulke MH: Prognostic significance of mTOR pathway component expression in neuroendocrine tumors. J Clin Oncol 2013;31:34183425.

63 Cives M, Strosberg J: Treatment strategies for metastatic neuroendocrine tumors of the gastrointestinal tract. Curr Treat Options Oncol 2017;18:14.
64 Yao JC, Shah MH, Ito T, Bohas CL, Wolin EM, Van Cutsem E, Hobday TJ, Okusaka T, Capdevila J, de Vries EG, Tomassetti P, Pavel ME, Hoosen S, Haas T, Lincy J, Lebwohl D, Öberg K; RAD001 in Advanced Neuroendocrine Tumors, Third Trial (RADIANT-3) Study Group: Everolimus for advanced pancreatic neuroendocrine tumors. $\mathrm{N}$ Engl J Med 2011;364:514-523.

65 Yao JC, Fazio N, Singh S, Buzzoni R, Carnaghi C, Wolin E, Tomasek J, Raderer M, Lahner H, Voi M, Pacaud LB, Rouyrre N, Sachs C, Valle JW, Delle Fave G, Van Cutsem E, Tesselaar M, Shimada Y, Oh DY, Strosberg J, Kulke MH, Pavel ME; RAD001 in Advanced Neuroendocrine Tumours, Fourth Trial (RADIANT-4) Study Group: Everolimus for the treatment of advanced, non-functional neuroendocrine tumours of the lung or gastrointestinal tract (RADIANT-4): a randomised, placebo-controlled, phase 3 study. Lancet 2016;387:968977.

66 Faivre S, Demetri G, Sargent W, Raymond E: Molecular basis for sunitinib efficacy and future clinical development. Nat Rev Drug Discov 2007;6:734-745.

67 Raymond E, Dahan L, Raoul JL, Bang YJ, Borbath I, Lombard-Bohas C, Valle J, Metrakos P, Smith D, Vinik A, Chen JS, Hörsch D, Hammel P, Wiedenmann B, Van Cutsem E, Patyna S, Lu DR, Blanckmeister C, Chao R, Ruszniewski P: Sunitinib malate for the treatment of pancreatic neuroendocrine tumors. N Engl J Med 2011;364:501-513.

68 Baldelli R, Barnabei A, Rizza L, Isidori AM, Rota F, Di Giacinto P, Paoloni A, Torino F, Corsello SM, Lenzi A, Appetecchia M: Somatostatin analogs therapy in gastroenteropancreatic neuroendocrine tumors: current aspects and new perspectives. Front Endocrinol (Lausanne) 2014;5:7.

69 Yerci O, Sehitoglu I, Ugras N, Cubukcu E, Yuce S, Bedir R, Cure E: Somatostatin receptor 2 and 5 expressions in gastroenteropancreatic neuroendocrine tumors in Turkey. Asian Pac J Cancer Prev 2015; 16:4377-4381.

70 Hankus J, Tomaszewska R: Neuroendocrine neoplasms and somatostatin receptor subtypes expression. Nucl Med Rev Cent East Eur 2016;19:111-117.

71 Vortmeyer AO, Lubensky IA, Merino MJ, Wang CY, Pham T, Furth EE, Zhuang Z: Concordance of genetic alterations in poorly differentiated colorectal neuroendocrine carcinomas and associated adenocarcinomas. J Natl Cancer Inst 1997;89:1448-1453.

72 Karkouche R, Bachet JB, Sandrini J, Mitry E, Penna C, Côté JF, Blons H, Penault-Llorca F, Rougier P, Saint André JP, Emile JF: Colorectal neuroendocrine carcinomas and adenocarcinomas share oncogenic pathways. A clinico-pathologic study of 12 cases. Eur J Gastroenterol Hepatol 2012;24:1430-1437. 